\title{
1 A density management diagram for Scots pine (Pinus sylvestris L.): a tool for assessing the forest's
}

protective effect

3 Giorgio Vacchiano* (1), Renzo Motta (1), James N. Long (2), John D. Shaw (3)

4 (1) Dipartimento Agroselviter, Università di Torino, Via Leonardo da Vinci 44, 10095 Grugliasco (TO) - Italy; (2)

5 Department of Wildland Resources and Ecology Center, Utah State University, 5230 Old Main Hill, Logan, UT 84322,

6 USA; (3) Forest Inventory and Analysis, Rocky Mountain Research Station, 507 25th Street, Ogden, UT 84401, USA.

* Corresponding author. Tel: +39 11 6705536; Fax: +39 11 6705546; Email: giorgio.vacchiano@unito.it

Abstract

11 Density Management Diagrams (DMD) are graphical tools used in the design of silvicultural regimes in even-aged forests. They depict the relationship between stand density, average tree size, stand yield and dominant height, based upon relevant ecological and allometric relationships such as the self-thinning rule, the yield-density effect, and site index curves. DMD effectively summarize stand structural descriptors, and are therefore helpful in determining stand characteristics needed to achieve a range of management goals.

We constructed a DMD for Scots pine (Pinus sylvestris L.) forests in the western Italian Alps. We used 210 sample plots from a region-wide forest inventory to determine the maximum density line and volume and top height isolines. Site index curves were used to assess time taken by stands to progress along their stand development trajectories.

The protection provided by Scots pine stands is most effective against rockfall, due to the frequent

21 occurrence of such forests in active source or transition areas. We used the DMD to identify combinations of 22 size and density representing optimal and sub-optimal protection from rockfall. An actual pine stand was used as a case study to illustrate how the diagram can be used to assess current functionality of the forest, forecast its likely development and compare alternative management strategies. 
1 Keywords: Density Management Diagram (DMD), Pinus sylvestris L., Protection Forests, Rockfall, Natural

2 hazards

\section{Introduction}

Scots pine (Pinus sylvestris L.) forests cover in Europe more than 28 million hectares $(20 \%$ of total forested area) (Mason and Alía, 2000). It is a stress tolerant, light demanding, usually early-seral species (Richardson, 1998). Pine forests play different ecological roles, ranging from pioneering communities established on abandoned agricultural land in parts of western Europe to stable, natural forest in Central and Northern EU as well as and on dry, marginal sites in the Alps and the Pyrenees where it was relegated by a century-long forest management history (Białobok, 1970; Ozenda, 1985). Increasing population density and emerging tourism in the alpine environment have resulted in increased demand for hydrological services and protection of settlements, activities and roads from natural hazards.

13 This has, in turn, focused attention on the protective function of mountain forests (Krauchi et al., 2000;

14 Motta and Haudemand, 2000). Due to their wide geographical distribution and the increase in forest cover 15 following post-war agricultural land abandonment (Barbéro et al., 1990; Poyatos et al., 2003; Poschlod et al., 2005; Caplat et al., 2006; Garbarino at el., 2006), mountain Scots pine stands have a priority role in both general protection from erosion and direct protection of human activities from natural hazards.

Among the natural hazards commonly affecting mountain areas, we believe the protection provided by Scots pine stands to be most effective against rockfall, due to the frequent occurrence of such forests in source or transition areas for falling boulders. The forest here plays its role by 1) preventing triggering of the event in source areas; 2) reducing kinetic energy of falling boulders in the transition zone; and 3) shortening distance traveled by rocks in accumulation areas (Dorren et al., 2004, 2007; Regione Valle d'Aosta and Regione Piemonte, 2006).

Several attempts have been made to describe structural features contributing to the protective function of a forest stand (Wasser and Frehner, 1996; Brauner et al., 2005; Frehner et al., 2005; Wehrli et al., 2006). Nevertheless, most approaches were based on a snapshot view of the forest, and granted little attention to the consequences of stand development on the stability of the protective role through time. 
1 Density Management Diagrams (DMD) are graphical models of even-aged stand dynamics (Newton, 1997).

2 They reflect fundamental relationships involving tree size, stand density, site occupancy, and self-thinning

3 (Jack and Long, 1996). They portray competition-induced mortality dynamics allowing users to forecast

4 stand development. Both current, and desired future, stand structure can be plotted on the DMD. Alternative management strategies to accomplish diverse objectives can therefore be devised and effectively compared

6 at a glance (Shaw and Long, 2007).

7 Jack and Long (1996) and Newton (1997) gave useful reviews of the history and features of DMD; such 8 diagrams exist for a number of species in North America (e.g., Drew and Flewelling, 1979; McCarter and

9 Long, 1986; Williams, 1994; Spathelf and Schneider, 2000; Long and Shaw, 2005; Sharma and Zhang, 2007;

10 Shaw and Long, 2007), Central and South America (Márquez-Linares and Alvarez-Zagoya, 1995;

11 Chauchard et al., 2001), Asia (Ando, 1962, 1968; Tadaki, 1963; Kumar et al., 1995), and Africa (Onyekwelu 12 et al., 2003; Biber et al., 2004). To date DMD exist for only a few European species (Sales Luis and

13 Fonseca, 2004; Anta and Gonzalez, 2005), and have not yet been used for describing structural

14 characteristics of protection forests.

15 Careful planning and management is required to sustain functioning protection forests. These forests usually serve other functions, such as wood production or recreation, which often results in conflicting management objectives. Therefore, managers often seek for decision supports to handle these conflicting purposes in an 18 efficient and sustainable way (Brauner et al., 2005).

A forest plays a direct protective function if it protects people, buildings and infrastructure against the impact of natural hazards such as avalanches or rockfall (Mayer and Ott, 1991). The aim of this research is to develop a DMD for Scots pine in the western Italian Alps, and test its suitability for assessment of present and future effectiveness of direct protection function. We reviewed the assumptions needed to apply DMD as

23 a silvicultural tool, and evaluated available references to optimal stand and tree parameters for maximizing 24 direct protection from rockfall. Our intent was to characterize on the DMD a suitability zone (sensu Shaw and Long, 2007) for optimal protection from rockfall. Last, a case study illustrated how silvicultural management strategies aimed at improving stand functionality can be effectively represented on the diagram. 


\section{Study area and data}

3 A forest inventory of Piedmont and Valle d'Aosta regions [Figure 1] provided data necessary for

4 construction of the DMD. Base grid size is $500 \mathrm{~m}$; sample plots are circular, with a radius between 8 and 15

5 m depending on overstory density (Camerano et al., 2007; Gottero et al., 2007). In each plot, the following

6 variables were recorded: UTM coordinates, elevation, slope, forest cover type, stand structure and

7 developmental stage, species and diameter at breast height (dbh) of all living individuals greater than $7.5 \mathrm{~cm}$,

8 total height of the tree closest to the plot center, percent canopy cover, number of stumps, snags and

9 seedlings, forest health conditions, pre-eminent forest function and management priority. The database

10 encompassed 457 plots where Scots pine was recorded as the dominant forest cover type. We computed

11 stand density, basal area on a per hectare basis and quadratic mean diameter (QMD) for Scots pine and for

12 all species combined. We calculated Reineke's (1933) Stand Density Index (SDI) according to the following

13 formulations, as modified by Daniel et al. (1979) [1] and Long and Daniel (1990) [2]:

$$
S D I_{Q M D}=N \cdot\left(\frac{Q M D}{25}\right)^{1.6}
$$

16

$$
S D I_{S U M}=\sum\left(N_{i} \cdot\left(\frac{d b h_{i}}{25}\right)^{1.6}\right)
$$

$\mathrm{N}$ is the number of trees per hectare, 
1 The two methods produce values of SDI essentially equal for even-aged stands, but more divergent with

2 increasing skewness of the diameter distribution (Shaw, 2000; Ducey and Larson, 2003). We computed the

3 ratio of $\mathrm{SDI}_{\mathrm{SUM}}$ to $\mathrm{SDI} \mathrm{QMD}_{\mathrm{QM}}$ for the purpose of separating relatively even-aged stands from stands with more

4 complex structures (Long and Shaw, 2005).

5 For the construction of the DMD and the evaluation of its inherent allometric relationships, inventory plots

6 were selected according to the following criteria (modified from Shaw and Long, 2007):

a. Species composition: more than $70 \%$ of basal area represented by Scots pine,

b. Structure: $\mathrm{SDI}_{\text {sum }}$ to $\mathrm{SDI}_{\mathrm{Dq}}$ ratio higher than 0.9 ;

c. Management impact: number of stumps less than $10 \%$ of living stems;

d. Sampling intensity: more than 10 measured trees per plot.

Selected stands, whose characteristics are summarized in Table 1, covered most sectors of Scots pine distribution in the study region [Figure 1], save for a few areas that were excluded due to the high occurrence of pine-broadleaves mixed stands or because of intense management.

\section{Size-density boundary}

21 Reineke's SDI [1] was computed for each plot assuming a self-thinning slope of 1.6, represented by the power coefficient in equations 1 and 2 . The $1.6^{\text {th }}$ power for the relationship between mean tree size and density was suggested by Reineke (1933) to be invariant for all plant communities experiencing maximum crowding. Due to limited plot size, certain plots may be located in overstocked patches that were not continuous beyond the plot boundary (Wilson et al., 1999). We estimated the maximum SDI as the $98^{\text {th }}$ 
1 percentile in the $\mathrm{SDI}_{\mathrm{SUM}}$ frequency distribution, a threshold we believe to better represent the stand-scale

2 maximum attainable stocking. The maximum size-density boundary represents maximum achievable density

3 for a given mean size, i.e., maximum exploitation of available growing space, and therefore maximum competition intensity (Yoda et al., 1963). We represented the maximum size-density boundary as a 1.6power function fitted through QMD-density combinations resulting in maximum SDI.

Several authors reported the evidence of a fall-off from the linear size-density boundary in older stands (White and Harper, 1970; Zeide, 1987; Cao et al., 2000; Shaw and Long, 2007), a pattern attributed both to the inability of old trees to fully recapture available resources following the death of other large trees, and to crown shyness proportionally increasing with tree height (Assmann et al., 1970; Long and Smith, 1992). Our data were insufficient to establish the presence or absence of a mature stand boundary; therefore we assumed

11 the maximum size-density relationship to be linear across the entire range of sizes and densities represented.

12 Relative density, expressed by the percent ratio between plot-level and maximum SDI Sum, $_{\text {, provided an }}$ 13 estimate of competition intensity in each stand. The usefulness of SDI as a relative density index is supported by its independence from stand age and site quality (Reineke, 1933). Relative density thresholds have been suggested to indicate crown closure, initiation of competitive dynamics, and the onset of self-thinning - the so-called Zone of Imminent Competition Mortality (ZICM) (Drew and Flewelling, 1979; Long, 1985). Lines representing such thresholds $\left(0.25,0.35\right.$ and 0.60 times $\mathrm{SDI}_{\max }$ respectively, according to suggestions by

18 Long, 1985) were plotted on the DMD to readily assess relative density of current and projected stands. Size19 density combinations indicative of crown closure were alternatively computed for each stand from an allometric relationship between stem diameter and crown width for open-grown trees (Hasenauer, 1997), assuming an uniform diameter distribution and triangular, regular spacing between trees.

\section{Top height and volume isolines}

When represented on the DMD, dominant height can be used jointly with an appropriate site index curve to assess the time needed for projected stands to reach particular structures, developmental stages or yields, thus introducing the temporal dimension in the diagram (Jack and Long, 1996). In order to plot such variable on the DMD we first modeled individual tree height as a function of diameter and plot basal area (which was 
1 shown by preliminary testing to be the most informative competition-related predictor, as compared to stand

2 density and plot basal area in larger trees):

3

4

$$
h_{i}=a_{\mathrm{o}}+a_{1} B A+a_{2} \log d b h_{i}
$$

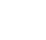

$$
\text { where } \mathrm{h}_{\mathrm{i}} \text { is tree total height }[\mathrm{m}] \text {, }
$$

$$
\text { BA is plot basal area }\left[\mathrm{m}^{2} \mathrm{ha}^{-1}\right] \text {, }
$$

$\mathrm{dbh}_{\mathrm{i}}$ is tree diameter at breast height $[\mathrm{cm}]$,

$\mathrm{a}_{0}, \mathrm{a}_{1}$ and $\mathrm{a}_{2}$ are model parameters.

The model was fit on systematically sampled pine trees with an available height measurement $(n=348)$, excluding trees with poor stem quality and with unrealistic height-to-diameter ratio $(<20$ or $>200)$, as compared with an ancillary dataset of reference trees from the same region (A. Nosenzo, unpublished data).

Stand dominant height was then computed as the mean height of the 100 thickest trees per hectare (Sharma et al, 2002). Selected stands were mostly pure and pine-dominated, thus the error due to extending the validity of the pine-specific height-diameter model to other species was minimal. Since the ratio of stand dominant height to QMD was best modeled by an inverse logarithmic function of stand density, we included the three variables in the following nonlinear regression model:

$$
Q M D=H_{100}\left(b_{1}-b_{2} \log N\right)
$$

where QMD is quadratic mean diameter at breast height [cm],

$$
\mathrm{H}_{100} \text { is stand top height, i.e. the mean height of the } 100 \text { thickest trees per hectare }[\mathrm{m}] \text {, }
$$

$\mathrm{N}$ is stand density [trees ha-1 ${ }^{-1}$, 
$b_{1}$ and $b_{2}$ are model parameters.

3 The sign of coefficient $b_{2}$ was constrained as negative during the non-linear fit in order to account for the

4 inverse influence of stand density on tree diameter. For a given height, trees growing in dense stands exhibit

5 smaller diameters than those growing in sparser stands, because of higher competition among individuals

6 (Temesgen and von Gadow, 2004). Substituting age for height and mean tree volume for diameter leads to

7 an alternative formulation of the yield-density effect characterized by Shinozaki and Kira (1956).

8 Single-tree volume equations provided by the regional inventory and parameterized for different species and

9 fertility classes were used to compute plot volume on a per-hectare basis. Stand yield was then expressed as

10 a function of QMD and density in order to generate volume isolines:

$$
V O L=c_{1} N\left(Q M D-c_{2}\right)^{c_{3}}
$$

where VOL is total standing volume $\left[\mathrm{m}^{3} \mathrm{ha}^{-1}\right]$,

19 The equation comes in the form of a shifted-power function, which best modeled the relationship between mean tree volume and QMD, and yielded slightly concave volume curves when plotted on the DMD (compare with McCarter and Long, 1986).

Allometric relationships portrayed on the DMD were assumed invariant across all sites (Weiner, 2004). A curve-fitting software (Hyams, 1997) aided in choosing the most suitable model forms. All models were

24 fitted using the nonlinear regression module of SPSS (SPSS Inc., 2004) and assessed for parameter significance and overall goodness-of-fit by computing adjusted $\mathrm{R}^{2}$ and root mean square error (RMSE). 
1 Model residuals were tested for normality and independence from predictors and from relevant stand and site

2 descriptors.

\section{Results I: plotting the DMD}

5 After screening, 210 sample plots were retained for determination of the maximum size-density line.

6 Maximum SDI for Scots pine stands in the sample was 1440. A long-standing concern centers on the most 7 appropriate method for parameter estimation of the limiting self-thinning equation (Zhang et al., 2005), a

8 difficult task when repeated inventory measurements are not available (Shaw, 2006). In a given sample only

9 a fraction of stands are in a true self-thinning mode, the rest being understocked for a number of reasons, e.g., insufficient regeneration density or intense disturbance impact (Tang et al., 1994). Application of a

11 binning method, i.e. improving selection objectivity by choosing one data point of maximum tree size for 12 each one of several intervals of equal log-density width (Bi and Turvey, 1997; Vacchiano et al., 2005) 13 yielded a self-thinning slope of -1.87 , with Reineke's slope of -1.6 well within a $95 \%$ confidence envelope 14 [Figure 2]. --Figure 2--

The Second National Swiss Forest Inventory (WSL, 2005) reported, for pure Scots pine plots ( $>70 \%$ relative basal area) in the Alpine region, a SDI $\max _{\max }$ of 1348 , as represented by the 98th percentile of the SDI distribution. Del Río et al. (2001) obtained a $\mathrm{SDI}_{\max }$ of 1444 for Scots pine in Spain, although they computed

21 a different self-thinning slope. Other referenced maximum SDI for Scots pine in Europe range from 840

22 (computed from Hynynen, 1993) to 1454 (computed from Palahí et al., 2002). Even though the datasets used 23 in these studies differed in stand origin (planted or naturally established), management intensity, degree of 24 stocking, and plot selection criteria, most estimates of $\mathrm{SDI}_{\max }$ were consistent with the present one. We compared our maximum against available yield tables for Scots pine in Europe (Wiedemann, 1949; Décourt, 1965; Hamilton and Christie, 1971; Marschall, 1976; Thren, 1987; Jansen et al., 1996), where SDI was 
1 computed from QMD-density combinations for the highest yield level (crop trees and removals). The

2 estimate from the current study was 17 to $74 \%$ higher than SDI from yield tables.

3 According to Reineke (1933), site fertility levels determine a higher or lower speed of advancement along 4 the same self-thinning trajectory. Other sources, however, suggested that maximum potential density is to be 5 understood as a site property (Assmann, 1970; Sterba, 1987). Different site qualities, therefore, have often

6 been characterized by different $\mathrm{SDI}_{\max }$, by varying either the intercept or the slope of the self-thinning line 7 (Sterba, 1981; Hynynen, 1993; Morris, 2002). A one-way ANOVA showed significant differences in mean 8 SDIsum values $(P<0.05)$ when grouped by forest site type (Camerano et al., 2004). We could not draw

9 definitive conclusions, since sample size was very small (3 to 63 data per site type) and because mean SDI is 10 likely to be affected by management history and age class distribution of the population being sampled.

11 Therefore, we defined a single $\mathrm{SDI}_{\max }$ value for all the plots, holding both the slope and the intercept of the 12 self-thinning line constant.

13 Relative SDI (i.e., the ratio between observed and maximum SDI) ranged between 0.09 and 1.00 for all Scots 14 pine stands $(\mathrm{n}=457)$. In most plots $(50 \%)$ relative SDI ranged between 0.35 and 0.60 ; only $19 \%$ of the stands 15 had a relative SDI greater than 0.60 [Figure 3]. Recent land use changes have likely played a major influence in shaping stand structure: many stands that had established on recently abandoned areas have not undergone self-thinning yet, but may soon be expected to do so (e.g., $40 \%$ of our stands had relative SDI greater than $1850 \%)$. --Figure 3--

Relative SDI associated with canopy closure ranged from 0.13 to 0.66 . The size-density relationship marking canopy closure-level crowding was steeper than the maximum size-density boundary, showing that the relation between canopy cover and the on-set of competition must change with other stand variables, e.g. increasing stand height. 
1 Table 2 summarizes best-fit estimates for equations [3], [4] and [5]; the isolines plotted on the DMD cover

2 the full range of top heights (5 to $30 \mathrm{~m}$ ) and the most common standing volumes (100 to $500 \mathrm{~m}^{3} \mathrm{ha}^{-1}$ )

3 measured on the selected plots.

--Table 2--

7 All regression parameters were significant at the $95 \%$ confidence level. Residuals were normally distributed

8 and unbiased against predictors. Nevertheless, we found some stand descriptors to have a significant

9 influence on the height-diameter curve, namely elevation and stand age (both linearly associated to tree

10 height residuals), aspect (stands on flat areas had higher-than-predicted top heights), site fertility as

11 expressed by the different sets of volume equations provided by inventory data, and forest cover type. Stand

12 volume, on the other hand, was unbiased but associated with a high prediction error (RMSE), dependent on a

13 few extreme outliers and most evident when representing mean bias for defined forest districts [Figure 4].

14 These results suggest users must confront with the choice between an average, wide-scale albeit rough

15 model, and recurring to separate diagrams for different locations, to better capture local variability of

16 allometric relationships. The full DMD for the study area is represented by Figure 5.

17

18

--Figure 4--

19 --Figure 5--

21 Case study

22 Methods II

23 Management of direct protection forests is aimed at maintaining or ameliorating stand structures allowing

24 acceptable reduction of the natural hazard (Motta and Haudemand, 2000). In order to illustrate the advantages of DMD in identifying management goals and design silvicultural strategies for specific stands, we superimposed on the diagram a "suitability zone" enclosing all combinations of size and density fulfilling 

the diagram can help assessing current functionality of the forest and planning for its future management.

3 We searched available literature for indications on structural parameters of forest fulfilling direct protection 4 against rockfall (Wasser and Frehner, 1996; Dotta and Motta, 2000; Mitchell, 2000; Brändli and Herold, 5 2001; Frehner et al., 2005; Regione Valle d'Aosta and Regione Piemonte, 2006), which are summarized by 6 the following (number in parentheses express criteria adopted for minimal protection):

a. Species composition: broadleaves contributing for more than $30(10 \%)$ to stand composition;

b. Minimum stand density: 400 (300) trees per hectare;

c. Vertical structure: two-layered, sufficient viable trees in two different stages of development;

d. Canopy cover: crown cover higher than $60 \%$;

e. Gaps in the stand: mean tree free distance $($ MTFD) $<30 \mathrm{~m}$. MTFD represents the probable mean

$$
M T F D=\frac{A}{N d_{\text {rock }}+\sum d b h_{i}}
$$

where A is stand area $\left[\mathrm{m}^{2}\right]$, $\mathrm{d}_{\text {rock }}$ is diameter of falling boulders [m], i.e., $0.3 \mathrm{~m}(0.5 \mathrm{~m}$ for minimal protection), $\mathrm{N}$ is stand density, $\sum_{\mathrm{dbh}_{\mathrm{i}}}$ is sum of tree dbh [m], here computed by multiplying QMD by tree density.

f. QMD higher than $1 / 3$ the diameter of the target boulder, i.e., $50(30) \mathrm{cm}$;

g. Tree slenderness lower than 80 (90) in dominant trees. A slenderness boundary may be represented on the DMD, substituting for the height term in equation [4]; 
h. Live crown ratio higher than $0.4(0.3)$ in trees or cluster of trees supporting the stability of the stand. A relative SDI of 0.50 should ensure a mean live crown ratio higher than $40 \%(0.60$ and $30 \%$ respectively for minimal protection), a figure representing a generally acceptable level of individual tree vigor (Long, 1985);

Where applicable, tree and stand structural requirements were plotted on the DMD in order to enclose a suitability zone for rockfall protection. Transition from non-effective to fully functional structures can be smoothed by assigning weights proportional to the protective effect associated with different values of the structural parameters under consideration; each functionality zone can then be characterized by a synthetic index of direct protection which is the sum of such weights (Motta and Haudemand, 2000). We adopted a simplified weighting scheme with a two-value scale, representing optimal and minimum acceptable protection [Figure 6].

--Figure 6--

The case study stand is located in the municipality of Antey Saint-André $\left(45^{\circ} 48^{\prime \prime} 0^{\prime \prime} \mathrm{N} ; 7^{\circ} 36^{\prime} 0^{\prime \prime} \mathrm{E}\right)$ at an elevation of $1200 \mathrm{~m}$ a.s.l. A permanent sample plot $(100 \mathrm{x} 80 \mathrm{~m})$ has been established in the transition zone of 21 a rockfall-prone slope. Scots pine represents $78 \%$ of the total number of trees, with a QMD of $22.7 \mathrm{~cm}$ and an overall density of 995 trees ha- ${ }^{-1}(\mathrm{dbh}>7.5 \mathrm{~cm})$. Mean live crown ratio is 0.4 ; mean crown cover is $51 \%-$ some gaps being sparsely located on recent scree slopes.

24 The estimate of standing volume provided by the DMD was very close to the ground truth (257 and 252 $\mathrm{m}^{3} \mathrm{ha}^{-1}$ respectively). Conversely, stand top height suffered from a large underestimation bias, that was likely due to the influence of less fertile stands in the calibration dataset. 

mean stand age to be 110 years. No site index curves were available for the study area, therefore we inferred them from available yield tables for Scots pine (Wiedemann, 1949) [Figure 7]. If Wiedemann's site indices were assumed to be appropriate, the dominant height computed by equation [4] would put the stand close to fertility class III, or SI=14 m (dominant height at base age of 100 years).

To explore options for sustaining the protective function, we modeled on the DMD 3 management options: a single-entry low thinning, a double-entry low thinning, and a selection thinning (i.e., options ii, iii, and iv in Table 3, where option i represents no management) and compared their outcome in terms of end-of-rotation yield, mean tree size and duration of direct protective role.

\section{Results II and Discussion}

15

In the study area, $30 \%$ out of a total 19,201 hectares of Scots pine stands are designated as protective forests, with 4,000 ha performing a direct protective function (Regione Valle d'Aosta and Regione Piemonte, 2006).

The case study stand is currently located at the outer edge of the zone of minimum effective rockfall protection. Current competition levels $(\mathrm{SDI}=890$, relative $\mathrm{SDI}=0.62)$ may soon result in increasing mortality rates, slowed tree growth, decreasing mean live crown ratio and an increasingly closed canopy, with an higher risk of damage due to biotic or abiotic disturbances. Evidence of ongoing self-thinning was found in the field: a high number of standing dead trees, regularly spaced surviving trees, a high mean stem slenderness (0.70, a value well-matched by DMD predictions) and a low mean live crown ratio. Individuals grown in a highly competitive environment will also suffer reduced individual vigor, which may further aggravate the negative impact of disturbance agents. All these factors would further hamper stand stability and hinder the fulfillment of an effective rockfall protection in the near future.

The rapid deterioration of the protective effect of the forest may be avoided by implementing silvicultural measures. Thinning reduces competitive pressure and promotes tree vigor and stability. Thinning entries can 
1 be represented on the DMD by plotting their effects in terms of mean tree size, stand density and top height.

2 A moderate thinning from below (i.e., with constant dominant height) removing $10 \%$ of standing total

3 volume, as proposed by a panel of experts (Regione Piemonte and Valle d'Aosta, 2006), would direct the

4 stand to a more effective zone for rockfall protection, and extend its functionality in time (as computed by

5 site index curves).

6 A selective thinning would further prolong stand suitability for optimal and minimum rockfall protection.

7 The proposed action involves removing $40 \%$ of standing mass, decreasing stand density and QMD so as to

8 relocate the stand on the lower boundary of the optimal protection zone. Thinning from above has been

9 suggested as a worthwhile practice in fertile Scots pine stands if compared with low thinnings (Favetta,

10 1996), whose weak selective power may not be strong enough to determine a relevant and timely response in

11 trees of an already mature age. An intense selection thinning pushing the stand back into minimum

12 protection zone might be the best choice if coupled with strategies to mitigate the higher rockfall hazard due

13 to reduced density, such as thinning in narrow strips perpendicular to the slope (if technically of

14 economically feasible) or positioning temporary support measures like wooden fences or lying logs.

15 Last, an additional low thinning, to be performed as soon as the stand again approaches the limits of the

16 optimal suitability zone, would allow maintaining constant crown closure throughout the rotation, mitigating

17 the impact of logging activities on advance regeneration, and preserving slender trees from sudden isolation.

18 The main drawbacks are represented by the high operation cost, due both to low quality and quantity of

19 removals, and by the reduced growth response mature trees would likely exhibit after such entry.

20 In modeling the consequences of silvicultural entries on the DMD, we assumed changes following artificial

21 thinning to be short-lived and not substantially affecting allometric relations during stand development

22 (Drew and Flewelling, 1979; Smith, 1989). While any of the active management options should sustain the

23 direct protective function for longer than the no-treatment option, the selection thinning regime promotes

24 active protection for the longest time span. However, time predictions should be considered with caution,

25 since age estimates are strongly dependent on the site index curve adopted in the analysis. 


\section{General remarks}

3 As shown by its application to a case study, a DMD for Scots pine forests incorporating an optimality zone

4 for rockfall protection is useful in managing stands where such a function represents the prioritized

5 silvicultural aim. The diagram allowed us to forecast the likely stand development should no management be

6 carried out, and to compare such option with different management strategies, whose timing and intensity

7 could be planned in an objective way based on relevant allometric relationships of the species under analysis.

8 The usefulness of DMD in protection forests is thus manifold, since they allow to assess current stand

9 structural conditions, forecast future stand development, and compare the effectiveness of different

10 silvicultural management strategies aimed at maximizing direct protective function.

11 Some of the shortcomings that may arise when using DMD to assess forest protective function include: i) a

12 limited capability to model resilience, i.e., the power to quickly recover an efficient structure following

13 adverse impacts (Grimm and Wissel, 1997; Brang, 2001). Potential for establishment can only be taken into

14 account indirectly by an estimate of residual growing space left by the parent stand (e.g., Moore and Deiter,

15 1992; Naumburg and DeWald, 1999). Regeneration models (Pukkala, 1987; Prévosto et al., 2003; Castro et

16 al., 2004) capable of assessing growing space requirements for the species of interest could help in designing

17 regeneration suitability zones within a species' DMD; ii) usability is limited to a geographic and structural

18 range similar to that used for diagram calibration (Drew and Flewelling, 1977). This makes mixtures

19 especially difficult to deal with, because the position of the self-thinning line and the estimate of overall

20 growing space are species-specific parameter (Weller, 1987; Hynynen, 1993, Inoue et al., 2004; Pretzsch,

21 2006; but see e.g. Puettmann et al., 1992; Solomon and Zhang, 2002 for successful representation of

22 mixtures in DMD); iii) the dynamics and management regimes described for the mean stand are not

23 necessarily true or optimum for any particular stand (Drew and Flewelling, 1979), i.e, there is a choice to be

24 made between generality and accuracy of the model. Hence, we consider the computation of local site index

25 tables a high-priority task in order to achieve more accurate stand growth predictions. Moreover, the poor

26 significance of some model functions, due to limited data availability, suggests the need of additional

27 sampling to validate the allometric relationships that represent the "backbone" of the diagram, and 
1 eventually, the importance of a properly designed inventory for future extension of the diagram to other

2 forest species.

3 Conversely, DMD are best applied when users need a large-scale, rapid tool to assess current and future

4 forest functionality, by means of overlaying time-independent structural requirements with the likely

5 development trajectory of the desired stands. The design of rockfall suitability zones is very sensitive to the

6 criteria adopted; we suggest to define suitability zones based on multiple requirements, so as to devise more

7 robust predictions. Ideally, stable forest ecosystems most effective against rockfall enter a steady state in

8 which small patches with alternating developmental phases provide the forest with a collective stability,

9 which is sub-optimal for protection on the short term, but optimal on the long term (Dorren et al., 2004). The

10 most stable forest structure is a small-scale mosaic of all classes of tree size and age (Ott et al., 1997; Motta

11 and Haudemand, 2000). A set of DMD would allow monitoring the functionality of each structural stage and

12 anticipating the impact of managing actions and disturbances on the stands that constitute such mosaic. We

13 therefore suggest the use of DMD as an effective support tool to management planning in forest playing a

14 direct protective role.

\section{Acknowledgments}

17 Support for this research was provided by Fondazione CRT and The Italian Fulbright Commission. The 18 authors wish to acknowledge to prof. A. Nosenzo and IPLA SpA for data availability, R. Berretti and J.R.

19 Genin for field work, W. Linquist for IDL programming, R. Justin DeRose and two anonymous reviewers 20 for their suggestions.

\section{References}

23 Ando, T., 1962. Growth analysis on the natural stands of Japanese red pine (Pinus densiflora Sieb Et Zucc),

24 II: analysis of stand density and growth. Bulletin of Government Forestry Experiment Station 147, 1-77.

25 Ando, T., 1968. Ecological studies on the stand density control in even-aged stand. Bulletin of Government Forestry Experiment Station 210, 1-153. 
1 Anta, M.B., González, J., 2005. Development of a stand density management diagram for even-aged

2 pedunculate oak stands and its use in designing thinning schedules. Forestry 78(3) 209-216.

3 Assmann, E., 1970. The Principles of Forest Yield Studies. Pergamon Press, Oxford, p. 506.

4 Barbéro,M., Loisel, R., Quézel, P., Richardson, D.M., Romane, F., 1998. Pines of the Mediterranean Basin, 5 In: Richardson, D.M. (Ed.), Ecology and Biogeography of Pinus. Cambridge University Press, Cambridge, 6 pp. 153-170.

Bi, H., Turvey, N.D., 1997. A method of selecting data points for fitting the maximum density-biomass line for stands undergoing self-thinning. Aust. J. Ecol. 22, 356-359.

Białobok, S. (Ed.), 1975. Scots Pine - Pinus sylvestris L.. Foreign Scientific Publication Dept., National

11 Biber, P., Onyekwelu, J.C., Stimm, B., 2004. Density management diagram as a tool for thinning recommendations in even-aged Nauclea diderrichii plantations in Omo forest reserve. The Nigerian Journal of Forestry 33, 59-69.

Brändli, U.B., Herold, A., 2001. Protection against natural hazards. In: Brassel, P., Lischke, H. (Eds.), Swiss national forest inventory: methods and models of the second assessment. Swiss Federal Research Institute WSL, Birmensdorf, pp. 231-253.

Brang, P., 2001. Resistance and elasticity: promising concepts for the management of protection forests in the European Alps. For. Ecol. Manage. 145, 107-119. support for evaluating forest protection effects against rockfall. For. Ecol. Manage. 207, 75-85.

21 Camerano, P., Gottero, F., Terzuolo, P.G., Varese, P., 2004. I tipi forestali del Piemonte. Blu Edizioni, Arezzo, p. 240.

Cao, Q.V., Dean, T.J., Baldwin, V.C., 2000. Modeling the size-density relationship in direct-seeded slash pine stands. For. Sci. 46, 317-321. 
1 Caplat, P., Lepart, J., Marty, P., 2006. Landscape patterns and agriculture: modelling the long-term effects of 2 human practices on Pinus sylvestris spatial dynamics (Causse Mejean, France). Landsc. Ecol. 21(5), 6573670.

4 Castro, J., Zamora, R., Hodar, J.A., Gomez, J.M., 2004. Seedling establishment of a boreal tree species 5 (Pinus sylvestris) at its southernmost distribution limit: consequences of being in a marginal Mediterranean 6 habitat. J. Ecol. 92(2), 266-277.

7 Chauchard, L., Sbrancia, R., Rabino, A., Penalba, M.G., Maresca, L., 2001. Modelos de crecimiento 8 diamétrico para Nothofagus dombeyi. Bosque 22(2), 53-68.

9 Daniel, T.W., Meyn, R.L., Moore, R.R., 1979. Reineke's stand density index: in tabular form in English and metric units with its applications. Research Report 37, Utah Agricultural Experiment Station, Logan UT, p.

1116. méthodes utilisées pour les construire. Ann. Sci. For. 22, 257-318.

Del Río, M., Montero, G., Bravo, F., 2001. Analysis of diameter-density relationships and self-thinning in non-thinned even-aged Scots pine stands. For. Ecol. Manage. 142, 79-87.

Dorren, L.K.A., Berger, F., Imeson, A.C., Maier, B., Rey, F., 2004. Integrity, stability and management of protection forests in the European Alps. For. Ecol. Manage. 195(1-2), 165-176.

Dorren, L.K.A., Berger, F., Jonnson, M., Krautblatter, M., Moelk, M., Stoffel, M., Wehrli, A., 2007. State of the art in rockfall-forest interactions. Schweiz. Z. Forstwes. 158, 128-141.

Dorren, L.K.A., Berger, F., Le Hir, C., Mermin, E., Tardif, P., 2005. Mechanisms, effects and management 21 implications of rockfall in forests. For. Ecol. Manage. 215, 183-195.

Dotta, A., Motta, R., 2000. Boschi di conifere montani: indirizzi selvicolturali. Blu Edizioni, Peveragno, p. 192. application to Monterey pine plantations. For. Sci. 23(4), 517-534. 
1 Drew, J.T., Flewelling, J.W., 1979. Stand density management: an alternative approach and its application to

2 Douglas-fir plantations. For. Sci. 25, 518-532.

3 Ducey, M.J., Larson, B.C., 2003. Is there a correct stand density index? An alternate interpretation. West. J. 4 Appl. For. 18(3), 179-184.

5 Favetta, A. (1996), Prove di diradamento in popolamenti di pino silvestre (Pinus sylvestris L.) dell'Alta Valle 6 di Susa. MSc thesis, Università degli Studi di Torino, p. 120.

7 Frehner, M., Wasser, B., Schwitter, R., 2005. Nachhaltigkeit und Erfolgskontrolle im Schutzwald 8 Wegleitung für Pflegemassnahmen in Wäldern mit Schutzfunktion. Bundesamt für Umwelt, Wald und 9 Landschaft, Bern, p. 654.

10 Garbarino, M., Lingua, E., Vacchiano, G., Motta, R., 2006. Scots pine forests in the NW Italian Alps: What 11 has changed in the last 50 years?. In: Lafortezza, R., Sanesi, G. (Eds.), Patterns and Processes in Forest 12 Landscapes. Consequences of human management. Proceedings of the 4th Meeting of IUFRO Working 13 Party 8.01.03, September 26-29, 2006 Locorotondo, Bari, Italy. Accademia Italiana di Scienze Forestali, 14 Firenze, pp. 523-528.

15 Gottero, F., Ebone, A., Terzuolo, P.G., Camerano, P., 2007. I boschi del Piemonte, conoscenze ed indirizzi 16 gestionali. Blu edizioni, Peveragno, p. 240.

17 Grimm, V., Wissel, C., 1997. Babel, or the ecological stability discussion: an inventory and analysis of 18 terminology and a guide for avoiding confusion. Oecologia 109, 323-334.

Gsteiger, P., 1989. Steinschlag, Wald, Relief: Empirische Grundlagen zur Steinschlagmodellierung. Diploma Thesis, Geographisches Institut, Universität Bern, Bern, p. 111.

21 Hamilton, G.J., Christie, J.M., 1971. Forest management tables (metric). Forestry Commission, London, p.

Hasenauer, H., 1997. Dimensional relationships of open-grown trees in Austria. For. Ecol. Manage. 96(3), 197-206. [software] http://curveexpert.webhop.biz/. 
1 Hynynen, J., 1993. Self-thinning models for even-aged stands of Pinus sylvestris, Picea abies and Betula 2 pendula. Scand. J. For. Res. 8(3), 326-336.

3 Inoue, A., Miyake, M., Nishizono, T., 2004. Allometric model of the Reineke equation for Japanese cypress

4 (Chamaecyparis obtusa) and red pine (Pinus densiflora) stands. J. For. Res. 9, 319-324.

5 Jack, S.B., Long, J.N., 1996. Linkages between silviculture and ecology: an analysis of density management

6 diagrams. For. Ecol. Manage. 86(1-3), 205-220.

7 Jansen, J.J., Sevenster, J., Faber, P.J. (Eds.), 1996. Opbrengsttabellen voor belangrijke boomsoorten in 8 Nederlan. Hinkeloord Report Nr. 17, Landbouwuniversiteit, Wageningen, p. 202.

9 Krauchi, N., Brang, P., Schönenberger, W., 2000. Forests of mountainous regions: gaps in knowledge and 10 research needs. For. Ecol. Manage. 132(1), 73-82.

11 Kumar, B.M., Long, J.N., Kumar, P., 1995. A density management diagram for teak plantations of Kerala in 12 peninsular India. For. Ecol. Manage. 74, 125-131.

13 Long, J.N., 1985. A practical approach to density management. For. Chron. 61, 23-27.

14 Long, J.N., Daniel, T.W., 1990. Assessment of growing stock in uneven aged stands. West. J. Appl. For. 5, $1593-96$.

16 Long, J.N., Shaw, J.D., 2005. A density management diagram for even-aged ponderosa pine stands. West. J. Appl. For. 20, 205-215.

Long, J.N., Smith, F.W., 1992. Volume increment in Pinus contorta var latifolia: the influence of stand development and crown dynamics. For. Ecol. Manage, 53(1-4), 53-64.

Márquez-Linares, M.A., Alvarez-Zagoya, R., 1995. Construcción de una guía de densidad para Pinus 21 cooperi var ornelasi con base en la clase de copa en Durango, México. Madera y Bosques 1(2), 23-36. Investigación Agraria: Sistemas y Recursos Forestales special 1, 317-335. 
1 McCarter, J.B., Long, J.N., 1986. A lodgepole pine density management diagram. West. J. Appl. For. 1, 6211.

3 Mitchell, S., 2000. Forest health: preliminary interpretations for wind damage. BC Ministry of Forests, 4 Forest Practices Branch, Victoria BC, p. 29.

5 Moore, M.M., Deiter, D.A., 1992. Stand density index as a predictor of forage production in northern 6 Arizona pine forest. J. Range Manage. 45(3), 267-271.

7 Morris, E.C., 2002. Self-thinning lines differ with fertility level. Ecol. Res. 17(1), 17-28.

8 Motta, R., Haudemand, J.C., 2000. Protective forests and silvicultural stability. An example of planning in 9 the Aosta Valley. Mount. Res. Dev. 20(2), 180-187.

10 Naumburg, E., DeWald, L.E., 1999. Relationships between Pinus ponderosa forest structure, light 11 characteristics, and understory graminoid species presence and abundance. For. Ecol. Manage. 124(2), $205-$ 12215.

13 Newton, P.F., 1997. Stand density management diagrams: review of their development and utility in stand14 level management planning. For. Ecol. Manage. 98,251-265.

15 Onyekwelu, J.C., Biber, P., Stimm, B., 2003. Thinning scenarios for Gmelina arborea plantations in south16 western Nigeria using density management diagrams. Journal of Food, Agriculture and Environment 1(2), $17 \quad 320-325$.

18 Ott, E., Frehner, M., Frey, H.U., Luscher, P., 1997. Gebirgsnadelwälder: Ein praxisorientierter Leitfaden für 19 eine standortgerechte Waldbehandlung. Paul Haupt, Bern, Stuttgart, Wien, p. 287.

20 Ozenda, P., 1985. La végétation de la chaîne alpine dans l'espace montagnard européen. Masson Editeur, 21 Paris, p. 331.

Palahí, M., Pukkala, T., Miina, J., Montero, G., 2002. Individual-tree growth and mortality models for Scots pine (Pinus sylvestris L.) in north-east Spain. Ann. For. Sci. 60, 1-10.

24 Perret, S., Dolf, F., Kienholz, H., 2004. Rockfalls into forests: analysis and simulation of rockfall 25 trajectories, considerations with respect to mountainous forests in Switzerland. Landslides 1, 123-130. 
1 Poschlod, P., Bakker, J.P., Kahmen, S., 2005. Changing land use and its impact on biodiversity. Basic Appl. Ecol. 6, 93-98.

3 Poyatos, R., Latron, J., Llorens, P., 2003. Land use and land cover change after agricultural abandonment.

4 The case of a Mediterranean Mountain Area (Catalan Pre-Pyrenees). Mount. Res. Dev. 23, 362-368.

5 Pretzsch, H., 2006. Species-specific allometric scaling under self-thinning: evidence from long-term plots in 6 forest stands. Oecologia 146, 572-583.

Prévosto, B., Hill, D.R.C., Coquillard, P., 2003. Individual-based modelling of Pinus sylvestris invasion after grazing abandonment in the French Massif Central. Plant Ecol. 168(1), 121-137.

9 Puettmann, K.J., Hibbs, D.E., Hann, D.W., 1992. The dynamics of mixed stands of Alnus rubra and 10 Pseudotsuga menziesii: extension of size-density analysis to species mixture. J. Ecol. 80, 449-458.

11 Pukkala, T., 1987. Simulation model for natural regeneration of Pinus sylvestris, Picea abies, Betula pendula 12 and Betula pubescens. Silva Fenn. 21(1), 37-53.

13 Regione Valle d'Aosta, Regione Piemonte, 2006. Selvicoltura nelle foreste di protezione: Esperienze e indirizzi gestionali in Piemonte e Valle d'Aosta. Compagnia delle Foreste, Arezzo, p. 224.

Reineke, L.H., 1933. Perfecting a Stand-Density Index for Even-Aged Forests. J. Agr. Res. 46(7), 627-638.

Richardson, D.M. (Ed.), 1998. Ecology and biogeography of Pinus. Cambridge University Press,

Sales Luis, J.F., Fonseca, T.F., 2004. The allometric model in the stand density management of Pinus pinaster Ait in Portugal. Ann. For. Sci. 61, 807-814.

Sharma, M., Zhang, S.Y., 2007. An improved stand density management diagram for jack pine grown in eastern Canada. North. J. Appl. For. 24(1), 22-29.

Sharma, M., Amateis, R.L., Burkhart, H.E., 2002. Top height definition and its effect on site index determination in thinned and unthinned loblolly pine plantations. For. Ecol. Manage. 168(1-3), 163-175.

24 Shaw, J.D., 2000. Application of stand density index to irregularly structured stands. West. J. Appl. For. 25 $15(1), 40-42$. 
1 Shaw, J.D., 2006. Reineke's stand density index: where are we and where do we go from here?. In:

2 Proceedings of the Society of American Foresters 2005 National Convention, October 19-23, 2005, Fort

3 Worth, TX [published on CD_ROM, Bethesda MD, Society of American Foresters], pp. [1]-13.

4 Shaw, J.D., Long, J.N., 2007. A density management diagram for longleaf pine stands with application to

5 red-cockaded woodpecker habitat. South. J. Appl. For. 31(1), 28-38.

6 Shinozaki, K., Kira, T., 1956. Intraspecific competition among higher plants. VII. Logistic theory of the C-D

7 effect. Journal of the Institute of Polytechnics of the Osaka City University, 7: 35-72.

8 Smith, N.J., 1989. A stand-density control diagram for western red cedar, Thuja plicata. For. Ecol. Manage. $9 \quad 27,235-244$.

10 Solomon, D.S., Zhang, L., 2002. Maximum size-density relationships for mixed softwoods in the 11 Northeastern USA. For. Ecol. Manage. 155(1-3), 163-170.

12 Spathelf, P., Schneider, P.R., 2000. Determination of a density management diagram as a decision tool for 13 growth control of Pinus elliottii Engelm stands. Forstwiss. Cent.bl. 119(3), 89-99.

14 SPSS Inc., 2004. SPSS 13.0 for Windows. Chicago IL [software].

15 Sterba, H., 1981. Natürlicher Bestockungsgrad und Reinekes SDI. Cent.bl. gesamte Forstwes. 98(2), 10116116.

17 Sterba, H., 1987. Estimating potential density from thinning experiments and inventory data. For. Sci. 33(4), $18 \quad 1022-1034$.

19 Tadaki, Y., 1963. The pre-estimating of stem yield based on the competition-density effect. Bulletin of 20 Government Forestry Experiment Station 154, 1-19.

21 Tang, S., Meng, C.H., Wang, Y.H., 1994. A growth and self-thinning model for pure even-aged mixed22 species stands. For. Ecol. Manage. 70, 67-73.

23 Temesgen, H., von Gadow, K., 2004. Generalized height-diameter models. An application for major tree 24 species in complex stands of interior British Columbia. Eur. J. For. Res. 123, 45-51. 
1 Thren, M., 1987. Kiefernproduktionsprogramme: Erstellt auf der Basis von Ertragskundlichen

2 Versuchsflächen und Einzelbäumen. MSc Dissertation, Universität Freiburg, p. 182.

3 Vacchiano, G., Lingua, E., Motta, R., 2005. Valutazione dello Stand Density Index in popolamenti di abete

4 bianco (Abies alba Mill.) nel Piemonte meridionale. It. For. Mont. 60(3), 269-286,

5 Wasser, B., Frehner, M., 1996. Minimale Pflegesmassnahmen für Wälder mit Schutzfunktion Wegleitung.

6 Bundesamt für Umwelt, Wald und Landschaft, Bern, p. 122.

7 Wehrli, A., Dorren, L.K.A., Berger, F., Zingg, A., Schönenberger, W., Brang, P., 2006. Modelling long-term

8 effects of forest dynamics on the protective effect against rockfall. For. Snow Landsc. Res. 80 (1), 57-76.

9 Weiner, J., 2004. Allocation, plasticity and allometry in plants. Perspect. Plant Ecol. Evol. Syst. 6(4), 207$10 \quad 215$.

11 Weller, D.E., 1987. A Re-evaluation of the $-3 / 2$ Power Rule of Plant Self-Thinning. Ecol. Monogr. 57(1), $12 \quad 23-43$.

13 White, J., Harper, J.L., 1970. Correlated changes in plant size and number in plant populations. J. Ecol. 58, $14 \quad 467-485$.

15 Wiedemann, E., 1949. Ertragstafeln der wichtigsten Holzarten bei verschiedener Durchforstung sowie 16 einiger Mischbestandsformen. M\&H Schaper, Hannover, p. 100.

17 Williams, R.A., 1994. Stand density management diagram for loblolly pine plantations in North Louisiana. 18 South. J. Appl. For. 18, 40-45.

19 Wilson, D.S., Seymour, R.S., Maguire, D.A., 1999. Density management diagram for northeastern red 20 spruce and balsam fir forests. North. J. Appl. For. 16, 48-56.

21 WSL (2005), Schweizerisches Landesforstinventar LFI Datenbankauszug der Erhebung 1993-95, Accessed October 4, 2005. Ulrich Ulmer. Eidgenössische Forschungsanstalt WSL, Birmensdorf.

23 Yoda, K., Kira, T., Ogawa, H., Hozumi, K., 1963. Self-thinning in overcrowded pure stands under cultivated 24 and natural conditions. Journal of Biology of the Osaka City University 14, 107-129.

25 Zeide,B., 1987. Analysis of the 3/2 power law of self-thinning. For. Sci. 33(2), 517-537. 
1 Zhang, L., Bi, H., Gove, J.H., Heath, L.S., 2005. A comparison of alternative methods for estimating the 2 self-thinning boundary line. Can. J. For. Res. 35, 1507-1514. 
1 Tables

\begin{tabular}{llllll}
\hline & Mean & Minimum & Maximum & St. Dev. 2 \\
& & & & & \\
\hline Plot area $\left(\mathrm{m}^{2}\right)$ & 359 & 142 & 707 & 126.8 & 3 \\
QMD (cm) & 21.6 & 10.7 & 45.4 & 5.59 & 4 \\
Density (trees ha $\left.{ }^{-1}\right)$ & 967 & 152 & 3318 & 534.9 & 5 \\
Basal area $\left(\mathrm{m}^{2}\right.$ ha $\left.^{-1}\right)$ & 32.18 & 5.33 & 89.75 & 15.162 & 6 \\
& & & & & \\
\% Scots pine on BA & $93.1 \%$ & $70.0 \%$ & $100.0 \%$ & $8.39 \%$ & 7 \\
Height of largest tree (m) & 13.8 & 8.1 & 21.8 & 2.52 & 8 \\
& & & & & \\
Standing volume $\left(\mathrm{m}^{3} \mathrm{ha}^{-1}\right)^{*}$ & 226.1 & 25.9 & 733.7 & 129.37 & 9 \\
\hline
\end{tabular}

*Volume equations were available only for 131 plots.

11

12 Table 1 - Summary of sample plots used for the construction of the DMD.

13

14 
Equation $3 \quad h_{i}=a_{\mathrm{o}}+a_{1} B A+a_{2} \log d b h_{i}$

\begin{tabular}{llllllr}
\hline & $\mathbf{a}_{0}$ & $\mathbf{a}_{1}$ & $\mathbf{a}_{2}$ & Adjusted R $^{2}$ & RMSE & 3 \\
\hline Estimate & -9.306 & 0.099 & 5.763 & 0.491 & $\pm 2.913 \mathrm{~m}$ \\
& & & & & &
\end{tabular}

$\begin{array}{llll}\text { Asymptotic SE } \quad 1.371 \quad 0.011 & 0.445\end{array}$

Equation $4 \quad Q M D=H_{100}\left(b_{1}-b_{2} \ln N\right)$

\begin{tabular}{lllll}
\hline & $\mathbf{b}_{1}$ & $\mathbf{b}_{2}$ & Adjusted R $^{2}$ & RMSE \\
\hline Estimate & 4.927 & 0.498 & 0.952 & $\pm 0.755 \mathrm{~cm}$ \\
Asymptotic SE & 0.078 & 0.012 & & \\
& & & & \\
\hline
\end{tabular}

Equation 5* $V O L=c_{1} N\left(Q M D-c_{2}\right)^{c_{3}}$

\begin{tabular}{llllll}
\hline & $\mathbf{c}_{1}$ & $\mathbf{c}_{\mathbf{2}}$ & $\mathbf{c}_{3}$ & Adjusted R $^{2}$ & RMSE \\
\hline Estimate & 0.001 & 5.057 & 1.935 & 0.952 & $\pm 263.27 \mathrm{~m}^{3} \mathrm{ha}^{-1}$ \\
Asymptotic SE & 0.001 & 1.202 & 0.128 & & \\
& & & & & \\
\hline
\end{tabular}

* Volume equations were available only for 131 plots.

6

7 Table 2 - Non-linear regression fit for allometric equations [3] to [5].

8 


\begin{tabular}{|c|c|c|c|c|c|}
\hline & Age $^{\mathbf{a}}$ & $\mathrm{H}_{100}(\mathrm{~m})$ & N (trees ha $\left.\mathbf{h}^{-1}\right)$ & QMD (cm) & $\operatorname{VOL}^{b}\left(m^{3} h^{-1}\right)$ \\
\hline Starting conditions & 110 & 15 & 995 & 22.7 & 257 \\
\hline i) Natural development ${ }^{\mathrm{c}}$ & $160^{\mathrm{d}}$ & 18 & 753 & 30 & 380 \\
\hline Time in optimal + minimal zone & \multicolumn{2}{|c|}{$0+0$ years } & & & \\
\hline ii) Low thinning (-10\% VOL) & 110 & 15 & 866 & 23 & 231 \\
\hline Time in optimal + minimal zone & \multicolumn{2}{|c|}{$0+25$ years } & & & \\
\hline iii) Selective thinning ( $-40 \%$ VOL) & 110 & 13 & 645 & 22 & 154 \\
\hline
\end{tabular}

\section{Time in optimal + minimal zone $\quad 20+$ indefinite $^{d}$}

$\begin{array}{llllll}\text { iv) Before low thinning } 2 & 130 & 15 & 600^{\mathrm{e}} & 26\end{array}$

$\begin{array}{llllll}\text { After low thinning } 2 & 130 & 15 & 400 & 29 & 187\end{array}$

Time in optimal + minimal zone $\quad 20+$ indefinite $^{d}$

2 a Estimated mean stand age. Time lapses are computed by using SI= $14 \mathrm{~m}$ (fertility class III).

$3 \quad$ b Volume estimated by DMD isolines (starting volume differs from true value).

$4 \quad{ }^{\mathrm{c}}$ Estimated trajectory of natural mortality driven by self-thinning, up to a QMD of $30 \mathrm{~cm}$ and a relative

5 density of 0.70 .

$6 \quad$ d Stand top height outside the range determined by yield tables for the chosen fertility class.

$7 \quad{ }^{\mathrm{e}}$ Density is allowed a slight reduction from the predicted value even during competition-free stand

8 development, due to the purported influence of rockfall disturbance.

10 Table 3 - Comparison of three density management alternatives: stand parameters at present and after each

11 silvicultural entry (computed from calibrated DMD relationships) and time allowance by suitable structure

12 for minimal or optimal rockfall protection. 


\section{$1 \quad$ Figure captions}

2 Figure 1 - Scots pine distribution in the study area and location of inventory plots selected for DMD fitting.

3 Figure 2 - Size-density combinations for the 210 plots included in the data set. Continuous line: maximum

4 self-thinning boundary for SDI= 1440, slope of -1.6 . Points above the line are characterized by size-density

5 combinations beyond the $98^{\text {th }}$ percentile of the SDI frequency distribution. Dashed line: average self-thinning

6 boundary computed by ordinary least square regression between maximum QMD points of 5 log-density

7 classes (white points). SDI computed by the binning method is 1310 , i.e., $91 \%$ of $\mathrm{SDI}_{\max }$.

8 Figure 3 - Relative density frequency distribution for $\mathrm{SDI}_{\max }=1440$. Relative density classes according to

9 Long (1985). Occasionally, highly crowded plots may attain size-density combination higher than what

10 overall stand conditions would allow (hence the values higher than 1).

11 Figure 4 - Mean prediction error of allometric models for tree height, stand top height and standing volume,

12 computed by forest district. A negative residual indicates variable underprediction.

13 Figure 5 - Density Management Diagram for Scots pine in the Western Italian Alps.

14 Figure 6 - Suitability zone for optimal (I) and minimal (II) protection from rockfall. Size-density

15 combinations determining complete canopy closure line (dash-and-dotted line) are superimposed on the

16 DMD. Suitability zones are defined by a. minimum crown closure; b. mean tree free distance; c. minimum

17 crown ratio; d. maximum tree slenderness; e. minimum QMD.

18 Figure 7 - Site index curves for Scots pine in Germany used in this study (adapted from Wiedemann, 1949).

19 Model form and measures of statistical significance were not specified by the source. 